\title{
Character Etiquette for Surfing in Cyberspace
}

\author{
Endrise Septina Rawanoko ${ }^{1, *}$ Kokom Komalasari², Suwarma Al Muchtar $^{3}$, Prayoga \\ Bestari $^{4}$
}

\author{
${ }^{1}$ Universitas Wisnuwardhana, Malang, Indonesia \\ 2,3,4 Universitas Pendidikan Indonesia, Bandung, Indonesia \\ *Corresponding author. Email: endriseseptina@gmail.com
}

\begin{abstract}
This article tries to find a formula for building a civilization with the character through education. The method used is literature study as part of a quantitative approach to research. As a result, three things need to be further developed in the world of character education for surfing in cyberspace, first, strengthening character education in schools, strengthening ethics in communication as one of developing a civilized and virtuous civilization, and third, the role of teachers in building education — character in school as a shield for students in surfing in cyberspace.
\end{abstract}

Keywords: character, citizen, etiquette.

\section{INTRODUCTION}

The extraordinary phenomenon occurs very quickly due to social media. Social media has positive things in the speed and sophistication of conveying news but does not rule out negative things in social media if it does not use ethics, norms, and manners. Social media is a term used to describe interactions between groups or individuals. They generate, share, and sometimes exchange ideas, images, videos, and more via the internet and virtual communities [1]. Social media is a place to communicate and interact with other people without any limitations of space and time.

The media as a bridge for political participation should be "generator citizens" who are willing to receive educational materials and are skilled at taking initiative, and are willing to participate in social life. So that citizens have the power to fight the hegemony of the partisan capitalist media. In the context of Citizenship Education, it is necessary to develop literacy for young citizens in the 21 st century, focusing more on preparing young citizens who have global insight who have the habit of thinking, heart, body, and soul who can work and prepare relationships and connections across differences and uniqueness, while maintaining and deepen one's sense of identity and integrity [2]. The challenge of preparing young citizens to compete today must begin to be directed at preparing them not only to compete locally and nationally but also to compete internationally. Therefore, the literacy of young citizens is developed to prepare them for the expected direction [3].

Social media has more harmful effects than positive [4]. Because students tend to spend more time on social media other than educational purposes, this tends to disrupt the learning environment, affecting their academic progress [4]-[6]. Furthermore, spending a lot of time on social networking sites can lead to a sedentary lifestyle and decreased levels of daily physical activity, which in turn can make them vulnerable to non-communicable diseases such as obesity, diabetes, and hypertension [7]-[9]. In addition, the use of social media harms mental health and can lead to depression and anxiety [4]. Therefore, due to the increasing number of such sites and the high demand for social media among students, it is vital to examine the intended use of social networking sites.

Media, in modern political studies, is considered as one of the pillars of democracy. Therefore, his involvement in the world of politics should provide a role that builds a better world. The role that is built is none other than the political participation of citizens. Participation in the governance system has long been seen as a pillar of democracy. However, the media are often used as a tool for the political hegemony of the rulers. The media are an extension of the rulers' interests, and political language has multiple meanings for smoothing and for the benefit of deceiving citizens, both of which are part of hegemonic politics as a condition for strengthening the power of the ruler [10]. 


\section{CITIZENS DIGITAL PARTICIPATION}

Two thousand years ago, ancient Greek philosophers proclaimed themselves citizens of a "world state". More than two centuries ago, American revolutionaries declared, "my country is this world". The idea of global citizenship is a deep and enduring part of culture man. Global citizenship views individuals with human rights, have the same human dignity and have similarities in the social and economic fields [11].

Global citizen and fellow global citizenship have a strong meaning as an effort to encourage citizens to have a global perspective" [12]. Being a global citizen is influenced and inseparable from the symptoms of globalization, where the rights of citizens today are no longer limited to the territory of the state but outside the territory of the country because one of the global symptoms is the increasing intensity of human movement from one place to another region to another [11].

The development of technology today so rapidly affects all aspects of life. The digital world today has a tremendous impact on changing patterns in social interactions. The power of social media, for example, affects the participation of young citizens in America. The McArthur Foundation Research Network on Participatory Politic survey results show that $41 \%$ of youth aged 15 to 25 years have participated in new political groups online, writing and disseminating blogs about political issues and political videos on their social media [13]. It shows the power of digital media to influence the political participation of young citizens. This condition is reinforced by the research of Martens \& Hobbs that there is a relationship between media literacy with increased knowledge and civic engagement of young citizens and contributes to their civic engagement as adults [14].

The digital world today has touched all aspects of life. The internet world connects everyone and provides everything. However, no one is responsible when something goes wrong when using the internet, and the error returns to the person who uses the internet [15]. The internet is a neutral, free, open, and unregulated technology. It means that we are all connected, but no one is in charge. In other words, the internet is a democracy, but without a constitution [15], [16]. Based on the opinion of Scoby and Friedman, it can be explained that the global world currently provides all the things we need and want through the internet. However, suppose something bad or unwanted happens. In that case, the internet is not responsible for it, meaning that someone must be responsible for each of them.

A broad understanding of digital literacy does not match the high growth of the internet and smartphones in Indonesia. Technology is facing a challenging transition. In the internet era, information flows continuously through social media, group chats, and news channels and cannot digest this information completely and correctly, but has a strong desire to share it with others immediately [17]. Unfortunately, some information can carry multiple interpretations and points of view. Some interpretations can lead to misunderstandings. In Indonesia, such cases are easy to find, most visible in the political sphere.

Responding to this for the democratic development of young citizens in the digital era, the challenge of preparing young citizens as citizens to compete today must begin to prepare them not only to compete locally and nationally but also to compete internationally. Citizenship is a political struggle that is often described in two important aspects: a legal status and citizenship as a practice [18]. In legal terms, a citizen is a creature who acts according to the law and has the right to obtain state protection as a practice refers to the status of citizens as political agents [19]. In the context of members of a state, it can be argued that citizenship is the relationship between the individual and the state and results in certain rights and responsibilities, which include the right to be heard and to participate in their government, the right to equal protection of the law, and the right to liberty. Such as freedom of religion and speech [20]. The fulfillment of the rights and obligations of citizens with this state requires the active participation of citizens. In the context of citizenship, it is called active citizenship, namely participating in society, community and/or political life, which is characterized by mutual respect, non-violence, in accordance with human rights and democracy including various participation activities such as voting, and also participation in people's daily lives [21], [22].

In the context of civic education, the development of literacy for young citizens of the 21 st century is more focused on preparing young citizens who have global insight as McIntosh [2] mentioned that global citizens have habits of mind, heart, body and soul that are able to work and prepare relationships and connections. Across their differences and uniqueness while maintaining and deepening one's own sense of identity and integrity. In the political context, when literacy is juxtaposed with civic, it becomes civic literacy. Citizens' knowledge and ability in overcoming social, political and state problems becomes a necessity along with political changes that require citizens to act autonomously [23].

The first orientation of Reichert and Print's research, shows that people with more advanced status in society are more likely to participate in civic and political activities, and have higher levels of civic knowledge, efficacy, and informative use of news media [24]. -[28]. The second orientation represents a direct consequence of civic discussion as a direct precursor of actual participation. The research shows that using news media 
on civic and political participation is indirect and transmitted through other variables. Potential mediators that have been identified include political knowledge and efficacy (ie, feelings of being able to understand and influence politics. Political knowledge is correlated with political efficacy, and political efficacy leads to active participation [29]. Political participation, political knowledge, and political efficacy are political variables. Other research also suggests that political efficacy affects participation. In efficacy, there is a feeling to influence other people, thus giving him participation because of political awareness [32] .

Social capital of social media as a new conceptual and empirical construction to complement face-to-face social capital. The results of research by de Zúniga, Barnidge, \& Scherman [33] that social media social capital is empirically different from face-to-face social capital. To realize a more healthy and participatory democracy, experts, as found above, have long established the positive effects of social capital, the values derived from resources embedded in social bonds with others that characterize the structure of opportunities and actions in society. Today, social media gives members of the digital community the ability to connect in new ways.

The pattern of citizens' political participation has changed with the use of media [34]. The citizen and media political participation pattern can be formulated in at least four dimensions, namely obedient, optional, individual and collective [35]. Obedient citizens feel obliged to stay informed about political developments, regard the political organization as important and regard voting as the most important civic duty [34], [36], [37]. Optional experiences provide opportunities for more than compliance to participate that allow citizens to reduce their political participation as a result of those choices [35]. As a result of the choice of participation, the individual has the independence to determine the choice of participation and self-actualization with a strong belief in the individual's ability to achieve change in society [36]. In the end, there is a collective consciousness that goes beyond "I" to "we" to create societal change [35], [36]. Moreover, a truly democratic society relies on an informed society capable of making political choices so that access to information is a basic right of citizens and a prerequisite of democracy itself [38].

\section{DIGITAL CHARACTER AND ETHICS}

The development of digital communication has the characteristics of global communication that crosses geographical and cultural boundaries. Meanwhile, each geographical and cultural boundary also has different ethical boundaries. Every country, even region, has its ethics, just as every generation has its ethics about privacy. Collective societies like Indonesians feel it's okay to talk about their illness or show the warmth of a relationship on social media. However, an individualistic society is not necessarily comfortable with this. Parents may feel normal and even proud to tell stories about their children. However, not necessarily are their children comfortable with the stories their parents tell on social media. Also, digital interactions between genders and between other social groups. Everyone will ask ethical questions. This means that we will interact and communicate with these different cultural differences in the digital space, so it is very likely that this global meeting will create new ethical standards.

Traditional ethics is offline ethics concerning old procedures, customs, and cultures which are the collective agreement of each community group, thus showing what is appropriate and inappropriate as a guide to the attitudes and behavior of community members. Contemporary ethics is electronic \& online ethics concerning procedures, customs, and cultures that have developed due to technology that allows sociocultural encounters to be broader and global. Digital ethics are interpersonal, social, organizational, national norms that govern how digital people/users should behave and behave in the digital world. The ethical management of this process affects the autonomy and honor/dignity/respect of people in the digital world. As the line between the digital and the real world continues to blur, this turn will have a profound impact on one's real world.

A digital forum community has certain rules and regulations that discuss the limits and the best way to use internet facilities [40]. In the digital world, we also know the internet label or the network label (netiquette), which is the label when it comes to the internet. The most important thing about netiquette is that we must always be aware that we interact with real people on other networks, not just with letters on the screen, but with actual human characters [40].

The challenges in implementing network etiquette are enormous because etiquette is more related to our personalities, and not all internet users adhere to this rule. However, in reality netiquette is not a complex thing, as long as our logic and common sense work without problems, we will have no difficulty in applying it, because netiquette comes from the things we usually do in social life [41]. This netiquette is also closely related to the realm of digital soft skills, which are part of the self-development that we must have. Digital literacy is "a concept that leads to mediation between technology and audience or users to practice digital technology productively" [42]. Digital media users can create and enforce rules and etiquette (netiquette), appropriate behavioral guidelines or behavior that violates the netiquette, knowledge and experience in 
dealing and acting in the digital world, and knowledge of digital evaluation.

Digital ethics refers to the study of the implications of technology on the social, political, and moral spheres of society. Capurro [43] has extensively researched the implications of digital information and communication technologies that exist in society. Today, there is a bad digital etiquette practiced by IT companies because of the gaps in existing laws. There is minimal consensus on the investigation of moral and political philosophy, with major disagreements even on basic digital ethics. The greatest challenge in digital ethics is the study of elements that cannot be seen with the naked eye, or that do not exist, with varying impacts and outcomes on social morals and established traditions. Uncontrollable risk is inherent because of the uncertainty created by new technologies, as well as questions about new technologies. Uncontrolled possibilities and outcomes in digital ethics are common due to the inability to predict the implications of new technologies on society due to the theoretical nature of perceived outcomes.

\section{CONCLUSION}

The greatest challenge in digital ethics is the study of elements that cannot be seen with the naked eye or that do not exist, with varying impacts and outcomes on established social morals and traditions. Uncontrollable risk is inherent because of the uncertainty created by new technologies, as well as questions about new technologies. Uncontrolled possibilities and outcomes in digital ethics are common due to the inability to predict the implications of new technologies on society due to the theoretical nature of perceived outcomes.

\section{REFERENCES}

[1] W. Akram and R. Kumar, "A study on positive and negative effects of social media on society," Int. J. Comput. Sci. Eng., vol. 5, no. 10, pp. 351-354, 2017, doi: 10.26438/ijcse/v5i10.351354.

[2] A. Rapoport, "A forgotten concept: global citizenship education and state social studies standards," J. Soc. Res., vol. 33, no. 1, pp. 91113, 2005.

[3] I. Arpannudin, "Literasi warga negara muda untuk pengembangan civic engagement di abad 21," in Prosiding Seminar Pendidikan Kewarganegaraan sebagai Bidang Ilmu dan Program Pendidikan dalam Konteks Penguatan Daya Saing Lulusan, 2016.

[4] H. C. Woods and H. Scott, "\#Sleepyteens: Social media use in adolescence is associated with poor sleep quality, anxiety, depression and low self-esteem," J. Adolesc., vol. 51, pp. 4149, Aug. 2016, doi: 10.1016/j.adolescence.2016.05.008.
[5] M. A. Bekalu, R. F. McCloud, and K. Viswanath, "Association of social media use with social well-being, positive mental health, and self-rated health: disentangling routine use from emotional connection to use," Heal. Educ. Behav., vol. 46, no. 25, pp. 695-80S, Dec. 2019, doi: $10.1177 / 1090198119863768$.

[6] R. Mahdiuon, G. Salimi, and L. Raeisy, "Effect of social media on academic engagement and performance: Perspective of graduate students," Educ. Inf. Technol. 2019 254, vol. 25, no. 4, pp. 2427-2446, Dec. 2019, doi: 10.1007/S10639019-10032-2.

[7] O. Melkevik et al., "Are associations between electronic media use and BMI different across levels of physical activity?," BMC Public Health, vol. 15, no. 1, p. 497, Dec. 2015, doi: 10.1186/s12889-015-1810-6.

[8] Y. Zou, N. Xia, Y. Zou, Z. Chen, and Y. Wen, "Smartphone addiction may be associated with adolescent hypertension: A cross-sectional study among junior school students in China," $B M C$ Pediatr., vol. 19, no. 1, pp. 1-8, 2019, doi: 10.1186/s12887-019-1699-9.

[9] F. B. Hu, M. F. Leitzmann, M. J. Stampfer, G. A. Colditz, W. C. Willett, and E. B. Rimm, "Physical activity and television watching in relation to risk for type 2 diabetes mellitus in men," Arch. Intern. Med., vol. 161, no. 12, p. 1542, Jun. 2001, doi: 10.1001/archinte.161.12.1542.

[10] S. Aminah, "Politik media, demokrasi dan media politik," Masyarakat, Kebud. dan Polit., vol. 19, no. 3, pp. 35-46, 2006.

[11] M. Gerzon, Global citizens. Bandung: Universitas Pendidikan Indonesia, 2012.

[12] A. A. Wahab and Sapriya, Teori dan landasan pendidikan kewarganegaraan. Bandung: Alfabeta, 2011.

[13] J. E. Kahne and E. Middaugh, "Digital media shapes youth participation in politics," $P h i$ Delta Kappan, vol. 94, no. 3, pp. 52-56, 2012, doi: $10.1177 / 003172171209400312$.

[14] H. Martens and R. Hobbs, "How media literacy supports civic engagement in a digital age," Atl. J. Commun., vol. 23, no. 2, pp. 120-137, 2015, doi: $10.1080 / 15456870.2014 .961636$.

[15] D. Scobey, "The specter of citizenship," Citizensh. Stud., vol. 5, no. 1, pp. 11-26, 2001, doi: $10.1080 / 13621020020025169$.

[16] L. T. Friedman, "Judgment not included," New Yorks Times, 1999.

[17] Daily Social, "Hoax distribution through digital platforms in Indonesia 2018," 2018.

[18] A. Osler and H. Starkey, Changing citizenship. Democracy and inclusion in education. New York, NY: Open University Press, 2005.

[19] F. K. Kalidjernih, Pusparagam konsep dan isu kewarganegaraan. Bandung: Widya Aksara, 2011. 
[20] A. Doğanay, "A curriculum framework for active democratic citizenship education," in School, curriculum and civic education for building democratic citizens, M. Print and D. Lange, Eds. Roterdam, Boston, Taipe: Sense Publisher, 2012, pp. 19-39.

[21] B. Hoskins et al., Measuring active citizenship in Europe. Luxembourg: European Commission Directorate-General Joint Research Centre Institute for the Protection and Security of the Citizen, 2006.

[22] B. Hoskins and M. Mascherini, "Measuring active citizenship through the development of a composite indicator," Soc. Indic. Res., vol. 90, no. 3, pp. 459-488, 2009, doi: 10.1007/s11205008-9271-2.

[23] K. Suryadi, "Inovasi nilai dan fungsi komunikasi partai politik bagi penguatan civic literacy," Pidato Pengukuhan Jabatan Guru Besat Ilmu Komunikasi Politik. Universitas Pendidikan Indonesia, Bandung, 2010.

[24] A. Vromen, “'People Try to Put Us Down...': Participatory Citizenship of'Generation X'," Aust. J. Polit. Sci., vol. 38, no. 1, pp. 79-99, 2003.

[25] N. Jung, Y. Kim, and H. G. De Zúniga, "The mediating role of knowledge and efficacy in the effects of communication on political participation," Mass Commun. Soc., vol. 14, no. 4, pp. 407-430, 2011.

[26] M. Sotirovic and J. M. McLeod, "Knowledge as understanding: The information processing approach to political learning," Handb. Polit. Commun. Res., pp. 357-394, 2004.

[27] A. Vromen, "Paul Keating is the prime minister, but who delivers the mail? A study of political knowledge amongst young people," Aust. J. Polit. Sci., vol. 30, no. 1, pp. 74-90, 1995.

[28] M. Fraile and S. Iyengar, "Not all news sources are equally informative: A cross-national analysis of political knowledge in Europe," Int. J. Press., vol. 19, no. 3, pp. 275-294, Jul. 2014, doi: $10.1177 / 1940161214528993$.

[29] F. Reichert and M. Print, "Mediated and moderated effects of political communication on civic participation," Information, Commun. Soc., vol. 20, no. 8, pp. 1162-1184, 2017.

[30] D. Carpini, X. Michael, and S. Keeter, What Americans know about politics and why it matters. New Haven: Yale University Press, 1996.

[31] D. V. Shah et al., "Campaign ads, online messaging, and participation: Extending the communication mediation model," J. Commun., vol. 57, no. 4, pp. 676-703, 2007, doi: 10.1111/j.1460-2466.2007.00363.x.

[32] M. J. Polonsky, A. M. N. Renzaho, A. S. Ferdous, and Z. McQuilten, "African culturally and linguistically diverse communities' blood donation intentions in A ustralia: integrating knowledge into the theory of planned behavior," Transfusion, vol. 53, no. 7, pp. 1475-1486, 2013.

[33] H. G. de Zúñiga, M. Barnidge, and A. Scherman, "Social Media Social Capital, Offline Social Capital, and Citizenship: Exploring Asymmetrical Social Capital Effects," Polit. Commun., vol. 34, no. 1, pp. 4468, 2017, doi: 10.1080/10584609.2016.1227000.

[34] W. L. Bennett, "Changing citizenship in the digital age," in Civic life online: Learning how digital media can engage youth, W. L. Bennett, Ed. Cambridge, MA: The MIT Press, 2008, pp. $1-24$.

[35] J. Ohme, "Updating citizenship? The effects of digital media use on citizenship understanding and political participation," Inf. Commun. Soc., vol. 0 , no. 0, pp. 1-26, 2018, doi: 10.1080/1369118X.2018.1469657.

[36] G. Mascheroni, "The practice of participation. Youth's vocaularies around on-and offline civic and political engagement," London, 35, 2015.

[37] J. Moeller, R. Kühne, and C. De Vreese, "Mobilizing youth in the 21st century: How digital media use fosters civic duty, information efficacy, and political participation," $J$. Broadcast. Electron. Media, vol. 62, no. 3, pp. 445-460, Jul. 2018, doi: 10.1080/08838151.2018.1451866.

[38] A. Joseph, Media matter, citizens care: the who, what, when, where, why, how, and buts of citizens' engagement with the media. Unesco, 2005.

[39] V. Venkateswaran, Digital ethics, no. April. Deloitte, 2021.

[40] M. Pane, Etiket dan netiket: Sopan santun dalam pergaulan dan pekerjaan. Jakarta: PT Kompas Media Nusantra, 2016.

[41] C. Ess, Digital media ethics, 2nd ed. Cambridge: Politeknik Negeri Bandung, 2014.

[42] N. Kurnia and S. I. Astuti, "Peta gerakan literasi digital di Indonesia: Studi tentang pelaku, ragam kegiatan, kelompok sasaran dan mitra yang dilakukan oleh Japelidi," INFORMASI, vol. 47, no. 2, pp. 149-166, Dec. 2017, doi: 10.21831/informasi.v47i2.16079.

[43] R. Capurro, "Digital ethics," 2009. http://www.capurro.de/korea.html (accessed Oct. 18, 2021). 